\title{
THE ARCHPRIEST HABBACUM ${ }^{1}$
}

\section{Abstract:}

The article talks about Habbacum (in Rus. — Avvakum) Petrov (1620-82), a prominent figure in the Russian Old Believers who opposed church reforms that were undertaken by Patriarch Nikon in the middle of the 17 th century. They particularly opposed the introduction of the three fingers sign of the cross instead of the centuries-old two fingers sign and the editing of ancient liturgical books, using new printed Greek editions. The author traces the tragic fate of the rebellious archpriest, who was brutally persecuted by the authorities and finally burned alive by their order in a wooden log house. Considerable attention in the article is paid to the literary works of the sufferer, including his autobiography, the first in the history of Russian literature.

\section{Keywords:}

Church reforms of the 17 th century, Siberian exile, petition to the tsar, burning in a log cabin, first Russian "Autobiography".

Аннотация: Л.К. ГАврюшинА. «ПротоПоП Аввакум».

В статье рассказывается об Аввакуме Петрове (1620-82) - видном деятеле русских старообрядцев, выступавших против церковных реформ, которые были предприняты патриархом Никоном в середине XVII в. Особенное неприятие в их среде вызывали введение троеперстного крестного знамения вместо многовекового двуперстного и правка древних богослужебных книг по новым печатным греческим изданиям. Автор прослеживает трагическую судьбу непокорного протопопа, подвергавшегося властями жестоким репрессиям и в конце концов заживо сожженного по их приказу в деревянном срубе. Значительное внимание уделено в статье и литературным сочинениям страдальца, в том числе и его первого в истории русской литературы жития-автобиографии: «Житие протопопа Аввакума, написанное им самим».

\section{Ключевые слова:}

Церковные реформы, ссылка, челобитная царю, сожжение в срубе, первая русская автобиография.

$\mathrm{H}^{3}$ abbacum (Petrov) was a writer, one of the main defenders of the old faith, a holy martyr who met his death for his confession of his faith, and the author of the first autobiography in Russian literature.

He was born in the village of Grigorovo, in the province of Nizhny Novgorod on 20 November 1620 (old style) into the family of a priest. At the beginning of his pastoral journey, he joined a "circle of pious adherents," which included the tsar's confessor, Stefan Vonifatiev, and won the protection of the latter. The task of the circle was to strengthen piety in the Russian church. As an archpriest

1 The work was carried out with the financial support of the RFBR (grant № 18-512-76004). 
in the city of Yuryevets-Povolsky, Habbacum called on parishioners to correct their demeanor, sternly rebuked them and introduced reading in unison, which made the services longer. This caused not only their discontent, but sometimes resentment.

Fleeing from an angry flock, Habbacum retired to Moscow, where his future ideological opponent, Nikon, already sat on the patriarchal throne. Having hitherto been a member of a circle, his views soon diverged from those of his associates. In February 1653, at the beginning of the Great Lent, Patriarch Nikon singlehandedly announced significant changes in the service and the replacement of the two-fingered sign of the cross (which had existed in the Russian church since ancient times) with a three-fingered one. Nikon's attempt to reform the service in accordance with Greek practice was perceived by some believers as a desire to violate the centuries-old foundations of Russian piety, provoking forceful protests and consequently leading to a split in the Russian church. Later it turned out that the editing of liturgical books during the reform was carried out not according to the old, but according to the newly printed Greek editions. In political terms, the reform was designed to meet both the Tsar's plans to put Russia at the head of the Orthodox world and Nikon's desire to affirm the superiority of the patriarchate over secular power.

The authorities' reprisals against the protestors could not but provoke a reaction from Habbacum, who fearlessly denounced the innovations. On 13 August 1653, during his all-night vigil in Moscow's Kazan Cathedral on Red Square, he was seized, put in chains, and then sent to Andronik's Monastery. There Habbacum was subjected to abuse and beating. Together with him, 60 of his associates were imprisoned. An intervention by the tsar saved him from being defrocked. In the same year Habbacum was exiled with his family to Tobolsk "for his outrages" and then sent on a trek to Siberian Dauria with commander A.F. Pashkov on an expedition replete with difficult trials and dangers. On the way he suffered many hardships and humiliations and survived the death of his two sons.

His return from exile through all of Siberia began in 1661. On the way to the capital, Habbacum preached and denounced the innovations introduced by Nikon, according to his own testimony in his biography: "in all cities and villages, in churches and in markets." In Siberia his fame as a defender of and martyr for the "old faith" was born. In Moscow he became the leader of the Old Believers, replacing the priest Ivan Neronov, who was already old and did not have the strength to fight actively.

In the capital, events at first developed favorably for the archpriest: the tsar and the boyars, opponents of Nikon, received him favorably. However, Habbacum spoke not only against the patriarch (which was welcomed by the boyars), but above all for the preservation of church principles. Therefore, the paths of Habbacum and his patrons diverged. In 1664, when he began to openly and publicly speak out against the new rites and compose angry petitions to the 


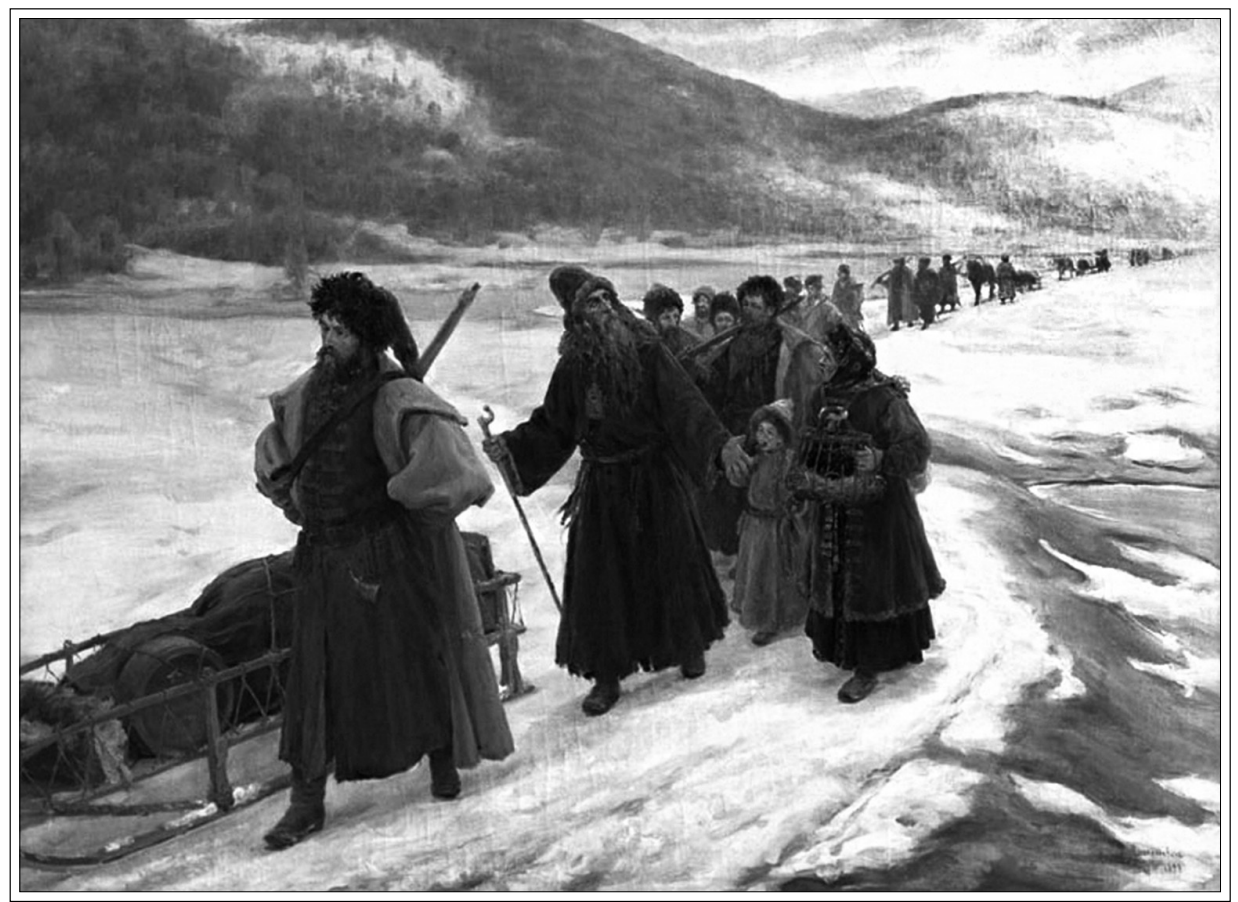

Habbacum's Journey through Siberia,

S. Miloradovich, 1898.

(State Museum of the History of Religion)

tsar, they decided to exile him and his family to the city of Pustozersk. However, they couldn't send them further. Soon, in connection with preparations for the Church Council of 1666, with the participation of the eastern patriarchs, arrests of the archpriest's associates began, and then he himself was brought to the capital for trial. Prior to the trial, Habbacum was kept in the Nikolo-Ugresh and Pafnutievo-Borovsk monasteries. The prisoner did not heed the admonitions of Paul, the Metropolitan of Krutitsa, who, according to Habbacum, tried to convert him to "his loving faith." He did not submit to the demands of the council, for which he, together with Deacon Fyodor Ivanov and the Suzdal priest Nikita Dobrynin, was defrocked and cursed in the Kremlin Assumption Cathedral.

The following year he was exiled to Pustozersk, where he was sent along with the priest Lazarus and the Deacon of Solovetsk Epiphanius (both of whom had their tongues cut off) and the Simbirsk priest Nicephor. Here Habbacum was imprisoned in an earthen cellar, but he did not give up. He continued to defend the old faith and sent exhortations to authorities and like-minded people until his execution, which was sought by Patriarch Joachim. On 14 April 1682, Archpriest Habbacum was burned in a log house, allegedly for "great blasphemy against the royal house," together with his three associates - Lazarus, Theodore, and 
Epiphanius. The Archpriest's dying words served as an idiosyncratic testament, in which he addressed the people, raising his hand with a two-fingered sign of the cross: "If you pray with this cross, you will never perish!"

It was during his 15-year-long exile in Pustozersk that Habbacum created his main works, including the aforementioned autobiography. He wrote it in 1675 at the urging of his spiritual father, the monk Epiphanius. This work is preceded by a lengthy theological introduction. Based on the definitions of Dionysius the Areopagite ("the truth is the Eternal, and the abandonment of the truth means the abandonment of the Eternal" and others), the author claims that the "new lovers," that is, the followers of Nikon, fell away from the truth, and therefore rejected God. What follows is a discussion of the spiritual consequences of the change of worship under Nikon, in particular, that the "four-way" chanting of "Hallelujah" is abhorrent to God as a violation of the Divine Trinity.

Habbacum's autobiography is one of the monuments that opened a new era in Russian literature and exemplified the formation of the author's self. The work of Habbacum is a documentary and artistic narrative and, at the same time, the most important source on the history of the Old Believers of the 17 th century. Its main, biographical part is a story rich in everyday details and dialogues about the author's life as an unshakable adherent of the old faith. It is stated in simple, sometimes rough, but very figurative language. In the text, the autobiography and quotes from Holy Scripture and Church Slavism coexist with colloquial expressions and descriptions of a naturalistic type.

Habbacum in an expressive and psychologically credible fashion sets out what happened to him, skillfully reproduces individual episodes and creates memorable images with a few strokes. These are the author's stories about the trials that befell him in the Spaso-Andronik monastery, where he, exhausted and hungry was fed tasty cabbage soup by "an angel or a man." There are attacks on him by lay people and priests, whom he had weaned "from fornication," as well as revenge by a "boss," whom he did not allow to take a daughter from her mother. A special place in his composition is occupied by the narrative of a grueling trek in Dauria, in which the touching image of Habbacum's faithful and courageous companion, his wife Anastasia Markovna, is especially notable.

Life of the Archpriest Habbacum, written by Himself was intended to explain to contemporaries the inevitability of suffering for those who oppose the coming Antichrist: "And now they torment everyone, they do not enjoin to believe in the old Son of God, the Savior of Christ, but they call to the new god, the antichrist." The text of the Life has come down to us in three author's editions and in the Pryanishnikov's copy from the 19th century. Among the nearly 60 works of Habbacum, the Book of Conversations should be noted, where church reform is presented as a return from the Gospel to the Old Testament, which marks the approach of the Last Judgment. The Book of Revelations, or the Everlasting Gospel (1679), contains a polemic on dogmatic issues with deacon Fyodor Ivanov. And in the Book of Interpretations (1673-76), in addition to interpretations of the 
books of the Old Testament, the text includes Habbacum's teaching on What is Christian mystery and how to live in the faith of Christ. Habbacum's epistolary heritage includes petitions to tsars Alexey Mikhailovich and Fyodor Alekseevich, letters to associates such as the noblewoman Theodosia Morozova, Eudocia Urusova, Abbot Theoktist and other persons.

Archpriest Habbacum is revered as a holy martyr in all Old Believer concordances. His memory is celebrated on 2 December (according to the old calendar) and 15 December (according to the new calendar).

Translated by Igor Kaliganov

\section{BIBLIOGRAPHY}

Zhitie protopopa Avvakuma, im samim napisannoe i drugie ego sochineniya. Moskva, 1960, 1990.

Zen'kovskij S. Russkoe staroobryadchestvo. Duhovnye dvizheniya XVII v. S. 1995.

Pustozerskaya proza: Protopop Avvakum. Inok Epifanij. Pop Lazar'. Diakon Fedor. Moskva,1989.

Robinson A.N. Tvorchestvo Avvakuma i obshchestvennoe dvizhenie v konce XVII v. // TODRL, 1962. T. 18. S.149-75.

\section{ILLUSTRATIONS}

1. Habbacum's Journey through Siberia, S. Miloradovich, 1898, State Museum of the History of Religion.

2. Cross of the Archpriest Habbacum.

3. View of Yuryevets-Povolsky. N. Chernetsov, 1851.

4. Holy Martyr Archpriest Habbacum. Volga region icon. Moscow, State Historical Museum, the end of the 17 th century - the beginning of the 18th century.

5. Archpriest Habbacum, modern icon.

6. Kozhurin K.Ya. Archpriest Habbacum. Edition of the series "Life of wonderful people." Moscow, 2011.

7. Patriarch Nikon.

8. Monument to Archpriest Habbacum in the village of Grigorovo. Bolshemurashkinsky district of the Nizhny Novgorod region. Sculptor V.M. Fangs.

9. Boyar Morozova visits Habbacum in prison, miniature of the 19th century.

10. Archpriest Habbacum, front sewing, 19th century (?). 